\title{
Sağlık Haberlerine Yönelik Yetişkin Tutumlarının Araştırılması
}

\author{
HARUN KIRILMAZ* \\ hkirilmaz@sakarya.edu.tr \\ ORCID ID: 0000-0001-6055-6826
}

\author{
YONCA YILDIRIM** \\ yncaay@gmail.com \\ ORCID ID: 0000-0001-8537-6602
}

\begin{abstract}
Öz: Bu araştırmanın amacı, yetişkinlerin kitle iletişim araçları yoluyla verilen sağhlk eğitimi haberlerine yönelik tutumlarının belirlenmesidir. Araştırma tarama modeline uygun olarak Nisan 2017'de Kocaeli Üniversitesi Tip Fakültesi Hastanesinde araştırmaya katılmaya gönüllü olarak katılmayı kabul eden 208 poliklinik hastası üzerinde uygulanmıştır. Araştırmada veri toplama aracı olarak Akgün (2014) tarafindan geliştirilen "Yetişkinlerin Kitle İletişim Araçlarıyla Verilen Sağlık Haberlerini Değerlendirme Anketi" ve "Kitle İletişim Araçlarıyla Verilen Sağlık Haberlerine Yönelik Tutum Ölçeği” kullanılmıştır. Verilerin analizinde tanımlayıcı istatistikler ve fark istatistikleri kullanılmıştır. Araştırmadan elde edilen bulgulara göre yetişkinlerin kitle iletişim araçlarıyla verilen sağlık eğitimi haberlerine yönelik gerçekçi bulma, önemli bulma ve genel tutumları orta düzeydedir. Yetişkinlerin sağlık eğitimi ihtiyaçların gidermede kitle iletişim araçlarını kullanma sıklığı arttıkça, kitle iletişim araçlarıyla verilen sağlık eğitimi haberlerini gerçekçi ve önemli bulma tutumları artmaktadır. Yetişkinlerin sağlık eğitiminde kullanılan kitle iletişim araçlarına güven düzeyi arttıkça kitle iletişim araçlarıyla verilen sağlık eğitimi haberlerini gerçekçi ve önemli bulma tutumları artmaktadır.
\end{abstract}

Anahtar Kelimeler: Yetişkin eğitimi, Sağllk eğitimi, Sağlık haberi, Kitle iletişim aracı.

\section{Giriş}

Günümüzde teknolojinin gelişimi ile birlikte bireylerin hastalık ve sağlık konularında bilgiye erişimlerinin daha karmaşık hale geldiği, mevcut bilgi birikimleri ile değerlendirme yapmalarına imkân olmadığı görülmektedir. Birey ve toplum sağl1ğının korunması ve geliştirilmesi için sağlık okuryazarlığı kavramı ortaya atılsa da, hâlihazırda kayda değer bir ilerlemenin sağlandığını söylemek mümkün değildir. Bu noktada bireylerin bilgiye erişiminde, belli bir konuda tutum ve kanaatlerinin oluşumunda medyanın, diğer bir ifade ile kitle iletişim araçlarının önemli rolü olduğu kabul edilmektedir. Kitle iletişim araçları bireylerin ve toplumun hastalık, sağlık vb. konularda bilgi edindikleri, tutum ve kanaatlerinin oluşmasında belirleyici olan yöntemlerin başında gelmektedir.

\footnotetext{
* Yrd. Doç. Dr., Sakarya Üniversitesi, İşletme Fakültesi, Sağlık Yönetimi Bölümü.

** Sakarya Üniversitesi, Sosyal Bilimler Enstitüsü, Sağlık Yönetimi Yüksek Lisans Öğrencisi.
} 
Sağllk toplumlar için her zaman vazgeçilmez bir olgudur. Günümüzde yaşanan siyasi, sosyal, teknolojik değişme ve gelişmeler sağlı hizmetlerini de etkilemektedir. Yetişkinlerin sağlıklarını korumaları ve geliştirmeleri için sağlık davranışlarının gelişmesi önem taşımaktadır. Yetişkinlerin tutum ve davranışlarının gelişmesi için yetişkin eğitimleri verilmeye başlanmıştır.

Yetişkin eğitimi; yetişkin sayılan kişilerin bilgilerini arttırmak, mesleki ve teknik açıdan ilerlemelerini sağlamak, becerilerini genişletmek ve kişisel gelişimlerine yardımcı olmak, toplumsal, ekonomik ve kültürel gelişimlerine katkıda bulunmak adına içerik, düzey ve yöntemi ne olursa olsun yaygın eğitim ya da zorunlu eğitimlerinin devamında yararlandıkları düzenli eğitim süreçlerinin tümü anlamına gelmektedir ${ }^{1}$.

Yetişkin eğitiminde kitle iletişim araçları önemli bir unsur olarak karşımıza çıkmaktadır. Dergi, gazete, televizyon gibi kitle iletişim araçları bilginin toplumun her kesimine ulaşmasını sağlamaktadır. Sağlık eğitimi haberleri de kitle iletişim araçları yoluyla toplumun her kesimine ulaşabilmektedir.

Sağlık eğitimi "bireyin sağlıklı olma koşullarını hazırlayan, sağlıklı olmayı mümkün kılan ve güçlendiren; ya da buna yönelik kolektif bir davranış için aynı etkileri yapan öğrenme yaşantılarının herhangi bir bileşenidir”. Sağlık eğitiminin yaş, cins, ırk, statü gözetmeksizin her insanı kapsaması gerekir. Yaygın eğitim yoluyla yetişkinlere kişisel sağlık bilgisi, hastalıkların önlenmesi ve kontrolü, aile sağlığı, tüketici sağlığı, insan vücudu ve görevleri, beslenme ve çevre sağllğı, büyüme ve gelişme, zihinsel ve duygusal sağlık, ilk yardım, güvenlik ve kazalardan korunma, zararlı alışkanlıklar, çevreyle iletişim, aile planlaması, cinsel yolla bulaşan hastalıklar, ana-çocuk sağlığı, hasta ve yaşlı bakımı, yeterli ve dengeli beslenme, ağız ve diş sağlığı, gibi konularda sağlık eğitimi verilebilir³.

Yetişkinlerin sağlık eğitimi ihtiyaçlarının belirlenmesi ve karşılanması için sağlık eğitimi haberlerine yönelik tutumlarının bilinmesi ve ona göre hareket edilmesi önem taşımaktadır. Yapılacak çalışma ile sağlık eğitimi haberlerine yönelik yetişkin tutumları araştırılacaktır.

$\mathrm{Bu}$ çalışmada sağlık haberlerine yönelik yetişkin tutumları araştırılmıştır. Bu amaçla Kocaeli Üniversitesi Tip Fakültesi Hastanesinde araştırmaya katılmayı gönüllü olarak kabul eden 208 poliklinik hastası üzerinde anket uygulanmıştır. Yapılan çalışma sonucunda yetişkinlerin kitle iletişim araçlarıyla verilen sağlık eğitimi haberlerine yönelik tutumlarının, sağlık konusundaki bilgi ihtiyaçlarını gidermede kitle iletişim araçlarından faydalanma sıklığına ve güven derecesine göre farklılaştı̆̆ tespit edilmiştir. Bunun yanı sıra yetişkinlerin sağlık konusundaki bilgi ihtiyaçlarını gidermede kitle iletişim araçlarından faydalanma sıklığı ile sağlık eğitiminde

1 Gülşah Penirci, "Yetişkin Eğitimi Kurslarının Yetişkin Eğitimi ve Yetişkin Öğrenen İlke ve Özelliklerine Göre İncelenmesi”, Yüksek Lisans Tezi, Marmara Üniversitesi, 2014, s.9.

2 Güler Çağatay ve Songül Vaizoğlu, “Toplum Sağlığı Eğitimi: Sağlık için Eğitim”, Yeni Türkiye, 39 (2001), s.796797.

3 Gülsüm Akgün, "Yetişkinlerin Kitle İletişim Araçları Yoluyla Verilen Sağlık Eğitimi Haberlerine Yönelik Tutumlarının Belirlenmesi”, Yüksek Lisans Tezi, Marmara Üniversitesi, 2014, s.2. 
kullanılan kitle iletişim araçlarına güven düzeyleri arasında anlamlı ilişki olduğu görülmüş̧ür.

\section{Kavramsal Çerçeve}

\section{Yetişkin Kavramı ve Yetişkin Eğitimi}

Yetişkin (adult) sözcüğü Latince büyümek (adolescere) fiilinin geçmiş zaman ortacından türemiştir, bu nedenle yetişkin bir kişi büyümüş bir kişi sayılır, fakat tanımlamadaki sorun yetişkinin sadece fiziksel özellikler bakımından değil, psikolojik özellikler bakımından da dikkate alınması gereğidir. Yetişkin kişinin fiziksel, psikolojik açıdan olgunlaşmış olduğu varsayılır ${ }^{4}$.

Ülkemizde ve dünyada "yetişkin" olarak adlandırılan bu kesimle ilgili birçok farklı tanımlamalar yapılmıştır. Yetişkin; kendini tanıyan ve başkalarının kendisini yetişkin olarak algıladığı kişidir. Yetişkinliği belirleyen üç temel özellik yaş, ruhsal olgunluk ve toplumdaki işlevlerdir ${ }^{5}$. Bazı kaynaklarda ise, 15 yaşını tamamlamış bireylerin yetişkin olarak kabul edebileceği öne sürülmektedir 6 .

Yetişkin kavramını bireyin bağımsızlığını esas alarak üç temel ölçü ile açıklamak mümkündür. Bunlar';

- Olgunluk ölçüsü: Bireyin bütün yeteneklerini kullanabilmesi, kişiliğinin oluşmas1, büyümesi ve gelişmesi.

- Uygun davranma ölçüsü: Diğer kişiler ve bizzat kendisi ile ilgili daha sağlıklı karar alabilmesi, uygun davranabilmesi.

- Bağımsız olma ölçüsü: Gönüllü olarak iş yapma, çalışma ve sorumluluk üstlenebilme durumudur.

Yetişkinlik genel olarak üç döneme ayrılarak incelenmektedir. Her bir dönemde bireylerin üstlenmekte oldukları toplumsal roller ve buna bağlı olarak yetişkinlerin beklentileri, umutları ve sorumlulukları değişmektedir.

Genç Yetişkinlik Dönemi: Yaklaşık on dokuz-yirmi yaşlarından başlayarak otuzlu yılların ortalarına kadar devam eden yetişkinlik yıllarıdır. Bu dönemde, birey bir mesleğe hazırlanarak meslek sahibi olmakta, ekonomik ve kişisel özgürlüğünü kazanmakta, karşı cinsle yakın ilişkiler kurmakta ve bir aile kurmaya yönelmektedir.

- Eş seçme,

- Bir aile kurma,

- Çocuk yetiştirme

- Bir evin işlerini yürütme,

- Çalışma hayatına başlama,

- Yurttaşlık sorumluluklarını yerine getirme,

4 Bekir Onur, Gelişim Psikolojisi, Ankara: İmge Kitabevi, 2008, s.55-56.

5 Rıza Okçabol, Halk Eğitimi (Yetişkin Eğitimi), Ankara: Ütopya Yayınevi, 2006, s.10.

6 Rıfat Miser, Halk Eğitimi ve Toplum Kalkınması, Ankara: Türk Tarih Kurumu Basımevi, 1999, s.15.

7 Firdevs Güneş, Yetişkin Eğitimi, Ankara: Ocak Yayınları, s.39. 
- Uygun sosyal gruba katılma.

Orta Yetişkinlik Dönemi: Yetişkinliğin orta yılları, yaklaşık otuzlu yaşların ortalarından altmışlı yaşlara kadar sürer. Bu dönem, orta yaş olarak da belirtilmektedir. Bu dönemde, bireyin üretkenliği, sorumluluklarının gelişmesi, farklı alanlara yönelik ilgilerinin artması, mesleki doyumun aranması, gelecek kuşakların yetişmesine yardım edilmesi gibi gelişimsel özellikler ön plana çıkmaktadır.

- Toplumun bir üyesi olarak yetişkinlere özgü sorumlulukları yerine getirme,

- Belli bir ekonomik yaşam düzeyine ulaşma ve bunu sürdürme.

- Ergenlik çağındaki çocuklarının sorumlu ve mutlu olmasına yardım etme,

- Yetişkinlere özgü boş zaman etkinliklerini geliştirme,

- Birey olarak eşiyle özdeşleşme,

- Orta yaşın getirdiği değişiklikleri kabullenme ve buna uyum sağlama,

- Yaşlı ana-babaya uyum sağlama.

İleri Yetişkinlik Dönemi: Yetişkinlik yıllarının yaklaşık altmışlı yaşlardan başlayarak yaşamın sonuna kadar devam eden dönemini içerir. Yaşlılık dönemi olarak da nitelendirilebilecek olan bu dönemde, bireyler azalan güce, bozulan sağlığa, emekliliğe uyum sağlamaya çalışırlar.

- Fiziksel güçteki ve sağliktaki düşüşe uyum sağlama,

- Emekliliğe ve azalan kazanca uyum sağlama,

- Yaş grubuyla açıktan ilişki kurma,

- Mutluluk verici fiziksel yaşam koşulları kurma,

- Toplumsal ve yurttaşlı görevlerini yerine getirme konusunda daha özenli davranma ${ }^{8}$.

Yetişkin eğitimi köklü bir geçmişe sahiptir. İnsanlar eskiden beri çevreyi tanımak, deneyim ve bilgilerini çevrelerine aktarmak, sürekli olarak öğrenme ve öğretme yaşantısında olmakla ilgilenmiştir. Bu süreç belirli bir gruptan zamanla toplumun geneline yayılmıştır'. Bilgilerin, yeteneklerin hemen eskidiği ve eksik kaldığı dünyada hangi düzeyde olursa olsun herkesin yetişkin eğitimi hizmetlerinden devamlı olarak yararlanmasına ve kendisini geliştirmesine ihtiyaç vardır. Bu sebeple yetişkin eğitimi giderek insanların ve toplumların geleceği için en önemli unsurlardan biri olmakta$\mathrm{d}^{1} \mathrm{r}^{10}$. Yetişkin eğitimin temel amacı, ülkenin yani toplumun problemlerinin çözümü için yetişkinleri eğitmektir ${ }^{11}$.

OECD’nin tanımına göre yaygın eğitim; zorunlu öğrenim dışına çıkmış ve asıl uğraşısı okula gitmek olmayan bireylerin, yaşamlarının herhangi bir aşamasında oluşa-

8 Jone Lowe, Dünyada Yetişkin Eğitimine Toplu Bakış, çev., Turhan Oğuzkan, Ankara: UNESCO Türkiye Milli Komisyonu, 1985, s.60-65.

9 Cevat Geray, Halk Eğitimi, Ankara: İmaj Yayınevi, 2002, s.15.

10 Rıfat Miser, "Küreselleșen Dünyada Yetişkin Eğitimi”, Ankara Üniversitesi Eğitim Bilimleri Fakültesi Dergisi, 35/1-2 (2002), s.56.

11 Sung-Jung Park, “Korean Women's Development Institute; South Korea the Change of South Korean Adult Education in Globalization", International Journal of Lifelong Education, 21/3 (2002), s.285 
cak öğrenme gereksinimlerini ve ilgilerini doyurmak için düzenlenen etkinlikler ya da programlardan oluşan bir süreçtir ${ }^{12}$.

Genel olarak yetişkin eğitiminin üç temel amacı vardır. Bunlar ${ }^{13}$;

- Toplumun gereksinim duyduğu bilgi, görgü, beceri ve yeterlilik düzeylerine sahip bir yetişkin toplumu oluşturmak,

- Yetişkinde, içinde yaşadığı toplumun gelişmesini ve kişilerin yaşamasını engelleyen sorunların üstesinden gelmekle ilgili bir anlayış geliştirmek ve yetişkini bu sorunların çözümüne hazırlamak,

- Kendisini gerçekleştirme amacına yönelik olarak tüm yetişkinlere tutum, bilgi, anlayış ve özelliklerini geliştirme olanakları sağlamak.

Ayrıca yetişkin eğitiminin genel amaçları arasında aklın geliştirilmesi, bireyin kendini gerçekleştirmesi, bireysel ve toplumsal gelişme yoluyla demokratik yaşam biçiminin geliştirilmesi ve toplumsal değişmede sayılmaktadır. Bu amaçlarla yetişkinlere; okuma-yazma eğitimi, mesleki yetiştirme, bilgi tazeleme, serbest zaman eğitimi, aile eğitimi, tüketici eğitimi, kültürel mirasın korunması ve geliştirilmesi, sağlık eğitimi, sosyal güvenlik eğitimi, bilgi okur-yazarı olma, yurttaşlık eğitimi, siyasal eğitim, mesleki ilerlemeye yönelik eğitim vb. eğitimler verilmektedir.

\section{Sağlık Haberi}

Sağlık haberi; hastalıkların önlenmesi, sağlığın korunması ve sağlık eğitimi alanlarını ve genel olarak da sağlı̆̆ın geliştirilmesi çabalarını kapsayan konularda yazılı, görüntülü ya da sesli iletiler halinde, okuyucu, izleyici ya da dinleyiciye ulaştırılan bilgileri kapsamaktadir.

Kitle iletişim araçlarıyla verilen sağlık eğitimi haberlerinin şu amaçlara yönelik olarak gerçekleştirildiği kabul edilmektedir ${ }^{14}$ :

- Sağlık konuları hakkında bilinci arttırmak,

- Sağlığın kamu gündemine yerleştirilmesine yardım etmek,

- Basit bilgi ve tekli mesaj iletmek,

- Başka kolaylaştırıcı faktörler mevcutsa davranış değiştirmek.

\section{Sağlık Ĕgitimi}

Dünya Sağlık Örgütü (DSÖ) eksperler komitesi sağlık eğitimini şöyle tanımlamıştır: "Sağlık eğitimi, kişilere sağlıklı yaşam için alınması gereken önlemleri benimsetmeye ve uygulamaya inandırmak; kendilerine sunulan sağlık hizmetlerini doğru olarak kullanmaya alıştırmak; sağlık durumlarını ve çevrelerini iyileştirmek amacıyla,

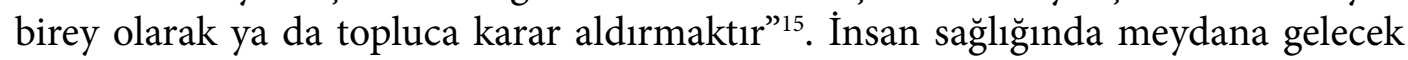

12 Okçabol, Halk Eğitimi (Yetişkin Eğitimi), s.20.

13 Ahmet Duman, Yetişkinler Eğitimi, Ankara: Ütopya Yayınevi, 2007, s.64.

14 İnci Çınarlı, Sağlık İletişimi ve Medya, Ankara: Nobel Yayın Dağıtım, 2008, s.140.

15 F. Zuhal Ulusoy Gökkoca, “Sağlık Eğitimi Açısından Temel İlkeler”, Sürekli Tip Eğitimi Dergisi, 10/10 (2001), s.371. 
olan ilerlemeler sağlık bilimlerinde gelişmelerin yanı sıra, insanların bu gelişmeler doğrultusunda yaşam biçimlerini değiştirmelerine bağlıdır. Bu değişmeyi sağlayan ve sağlığın korunmasında, geliştirilmesinde bir yöntem olarak işlevini sürdüren sağlık eğitimini temel amaçlarını Dünya Sağlık Örgütü üç maddede toplamıştır ${ }^{16}$ :

- Sağlığın değerini bireylere ve topluma anlatmak, inandırmak,

- Bireyleri ve toplumu, sağlık sorunlarını kendi kendine çözmeye alıştırmak,

- Bireyleri ve toplumu, sağlık kuruluşlarından azami ölçüde faydalanmaya alıştırmak.

Sağlık eğitimin planlanması, şu aşamalarda gerçekleşiriri

- Eğitim ihtiyaçlarının (sorunun ) belirlenmesi

Yapılmış bilimsel çalışmaların verilerinden yararlanılmalı. Toplum tanıtıcı bütün yazılı kaynaklar, raporlar, istatistikler ve diğer belgeler incelenmelidir.

- Amaç ve hedef grupların belirlenmesi

Amaçlar, eğitim uygulamaları sonunda bireylere kazandırılmak istenen son davranışı ifade eder. Bunun için hazırlanan amaçlar eğitim sonunda ölçmek istediğimiz şeyleri kapsamalı ve ölçülebilir nitelikte olmalıdır. Eğitim ihtiyacı olan bireyler hedef gruptur.

- Planın hazırlanışı

Amaçlara ulaşabilmek için önceden belirlenmesi ve tasarlanması gereken işler vardır. Bu işlerin belirlenmesine ve belirli bir sıraya göre dizilmesine planın hazırlanışı denir. Sağlık eğitimi alacak kişilerin demografik özellikleri, eğitim yapılacak yerin özellikleri, eğitim yöntemi, süresi belirlenerek sağlık eğitimleri planlanır.

- Eğitim uygulamalarının başlatılması

Belirlenen hedef gruba kazandırılması amaçlanan konuların hayata geçirilmesi olayıdır. Uygulamaların başarısı eğitimci ve eğitilenin çabası, konu, yöntem, araç-gereç ve çevre düzenlemesi ile doğru orantılıdır.

- Değerlendirme

Değerlendirme de amaçlara ulaşılıp ulaşılmadığını kontrol edilmeli, plan ve programlarda aksayan yerler tespit edilip bunların giderilmesine çalışılmalıdır. Ayrıca zaman, insan gücü ve mali kaynağın en verimli şekilde kullanımın sağlayıp, eğitim çalışmasının bir sonraki çalışmalara örnek olması sağlanmalıdır. İlk değerlendirmede eğitim öncesi mevcut durum saptanır. Ara değerlendirmede eğitimin seyrini belirlemek ve kazandırılan davranışları geliştirmek.

16 Mehmet Özden, Sağlık Eğitimi, Ankara: Feryal Matbaacılık, 1993, s.3,28.

17 Mehmet Özden, Sağlık Eğitimi Ders Kitabı, Ankara: Kadığlu Matbaacılık, 1991, s.69-71. 


\section{Sağlık Eğitiminde Kitle İletişim Araçlarının Etkisi}

"Bilginin paylaşımı” olarak da nitelendirilen iletişim, günümüzde bir yönüyle bireylerin ve dolayısıyla toplumların gelişmesine katkıda bulunan en önemli araçlardan biri sayılmaktadır. İletişimin toplumsal temelinde sorun çözme yatar. Günümüz toplumlarında iletişim ve iletişim süreci, sosyal etkileşim, toplumun istek ve beklentilerinin yerine getirilmesinin yanı sıra ulusal ve uluslararası değerlerin korunması açısından da önemlidir. Bazı demokratik toplumlarda, iletişim yoluyla bilgiye ulaşma, genelde bir hak olarak düşünülür; ancak bilgi edinmenin yalnızca bir hak değil, bir gereksinim olduğu gözden kaçar. Bilgi olmadan, birey kendini toplumun bir parçası olarak hissedemez ${ }^{18}$.

Yazılı, sesli veya görsel unsurların dağıtılıp, yayımlanmasına yardımcı olan her türlü teknik iletişim aracına kitle iletişim aracı denilmektedir. Bu süreç boyunca izleyiciyi, okuru, çeşitli yollardan etkilemek için ileti tasarlayan profesyonel iletişimciler, bu amaç doğrultusunda kitle iletişim araçları olarak anılan televizyon, radyo, gazete, internet, bilgisayar, sinemayı kullanmaktadır ${ }^{19}$.

Yaşadığımız dönemde teknoloji büyük bir hızla gelişmekte, buna paralel olarak da kitle iletişim araçlarının etkinlikleri artmaktadır. Günümüzde gazete, dergi, radyo, televizyonun yanı sıra internet vasıtasıyla iletişim ağları kurulmuş ve bu alanda bambaşka boyutlar ortaya çıkmıştır. Böylece kitle iletişim araçları insan hayatının ayrılmaz parçaları haline gelmişlerdir ${ }^{20}$.

Günümüzde sağlıkla ilgili her türlü belgeseller, haber bültenleri, gazetelerin sağlık köşeleri ve sağlık sayfaları, televizyondaki sağlık programları, diziler ve kimi filmler; sağlıkla ilgili olumlu davranışa yöneltici, sağlığı koruyucu ve geliştirici mesajların iletildiği kitle iletişim ortamları olarak düzenlenebilmektedir.

Sağlığın korunması ve geliştirilmesi çalışmalarında kitle iletişiminin rolü kısaca şu şekilde ortaya konulabilir ${ }^{21}$.

- Kamunun farkındaliğını arttırmak: Kamuya enformasyon sağlayarak, sağlığını bozan davranışlarının etkilerini, sağlıklı davranış ve yaşam biçimleri benimsenmesinin yararlarını hatırlatarak.

- Bir fikir ortamı yaratmak: Bir konu ile ilgili belirgin özelliği koruyarak ve o konu hakkında düşünüldüğünden emin olma yoluyla politika değişikliğine neden olarak.

- Tutumları biraz olsun değiştirmek ve davranış değişikliği sağlamak: Hastalığın etkileri, sağlığa zararlı davranışların sonuçları ve önleyici davranışın faydaları üzerinde durarak medya sağlığın geliştirilmesinde rol oynayabilmektedir.

Toplumun sağlık konusunda bilinçlendirilmesinde, sağlı̆̆ın korunması ve geliştiril-

18 Atilla Girgin, Gazeteciliğin Temel İlkeleri, İstanbul: Der Yayınları, 2008, s.2-17.

19 Erkan Yüksel, Medyanın Gündem Belirleme Gücü, Konya: Çizgi Kitabevi Yayınları, 2001, s.4.

20 Vedat Demir, Medya Etiği, İstanbul: Beta Basım Yayın Dağıtım, 2006, s.15-16.

21 Çınarlı, Sağlık İletişimi ve Medya, s.95-96. 
mesinde sağlık kuruluşları tek başına yetersiz kalmaktadır. Kitle iletişim araçları ile iletişim, kısa sürede çok geniş kitlelere ulaşılmasında en etkili iletişim yollarından biridir. Bu nedenle yetişkinlerin sağlık eğitiminde, kısa sürede geniş kitlelere ulaşılmasında, tutumların oluşması ve değiştirilmesinde kitle iletişim araçlarının etkisi ve önemi oldukça fazladır.

\section{Araştırma}

\section{Amaç}

$\mathrm{Bu}$ araştırmanın genel amacı, yetişkinlerin kitle iletişim araçları yoluyla verilen sağlık eğitimi haberlerine yönelik tutumlarının belirlenmesidir.

$\mathrm{Bu}$ amaçla cevaplandirılacak sorular şunlardır:

- Yetişkinlerin, kitle iletişim araçları yoluyla verilen sağlık eğitimi haberlerine yönelik tutumları ne düzeydedir?

- Cinsiyete göre yetişkinlerin, kitle iletişim araçları yoluyla verilen sağlık eğitimi haberlerine yönelik tutumlarında değişim olur mu?

- Yaşa göre yetişkinlerin, kitle iletişim araçları yoluyla verilen sağlık eğitimi haberlerine yönelik tutumlarında değişim olur mu?

- Kronik hastalık varlığına göre yetişkinlerin, kitle iletişim araçları yoluyla verilen sağlık eğitimi haberlerine yönelik tutumlarında değişim olur mu?

- Hastalık/ameliyat geçirme durumuna göre yetişkinlerin, kitle iletişim araçları yoluyla verilen sağlık eğitimi haberlerine yönelik tutumlarında değişim olur mu?

- Kendini bedenen sağlıklı hissetme durumuna göre yetişkinlerin, kitle iletişim araçları yoluyla verilen sağlık eğitimi haberlerine yönelik tutumlarında değişim olur mu?

- Kendini ruhen sağlıklı hissetme durumuna göre yetişkinlerin, kitle iletişim araçları yoluyla verilen sağlık eğitimi haberlerine yönelik tutumlarında değişim olur mu?

- Sağlık konusundaki bilgi ihtiyaçlarını gidermede yetişkinlerin kitle iletişim araçlarından faydalanma sıklığı nedir?

- Yetişkinlerin, sağlık eğitiminde kullanılan kitle iletişim araçlarına güven derecesi nedir?

\section{Yöntem}

Araştırma, yetişkinlerin kitle iletişim araçlarıyla sunulan sağlık haberlerine yönelik tutumlarını belirlemek amacıyla yapılan tanımlayıcı bir çalışmadır. Araştırmada veri toplama aracı olarak Akgün (2014) tarafından geliştirilen "Yetişkinlerin Kitle İletişim Araçlarıyla Verilen Sağlık Haberlerini Değerlendirme Anketi” ve "Kitle İletişim Araçlarıyla Verilen Sağlık Haberlerine Yönelik Tutum Ölçeği” kullanılmıştır.

01.04.2017-05.04.2017 tarihleri arasında Kocaeli Üniversitesi Tip Fakültesi Hastanesinde Çalışan Personele ve Dâhili Anabilim Dalı Poliklinikleri Bekleme Salonu ve 
Cerrahi Tip Bilimleri Anabilim Dalı Poliklinikleri Bekleme Salonunda 08.00-16.00 saatleri arasında bekleyen 25 yaş ve üstü araştırmaya katılmaya gönüllü olan 208 kişi araştırmanın örneklemini oluşturmuştur. Bu araştırmanın çalışma evrenini 25 yaş ve üstü yetişkinler oluşturmaktadır. Araştırmanın örneklemi; evrenden kolay ulaşılabilir durum örneklemesi ve ölçüt örnekleme yöntemi ile seçilerek oluşturulmuştur. Kolay ulaşılabilir durum örneklemesi; araştırmacının diğer örnekleme yöntemlerini kullanma olanağının olmadığı durumlarda yakın olan ve erişilmesi kolay olan durumu seçtiği örnekleme yöntemidir. Ölçüt örnekleme ise; önceden belirlenmiş bir dizi ölçütü karşılayan bütün durumların çalışılmasıdır ${ }^{22}$.

Araştırmada elde edilen veriler SPSS (Statistical Package for Social Sciences) 16.0 programı kullanılarak analiz edilmiştir. Verileri değerlendirilirken tanımlayıcı istatistiksel metotları (sayı, yüzde, ortalama, standart sapma) kullanılmıştır. Niceliksel verilerin karşılaştırılmasında iki grup arasındaki farkı t-testi, ikiden fazla grup durumunda parametrelerin gruplar arası karşılaştırmalarında Tek yönlü (One way) Anova testi ve farklılığa neden olan grubun tespitinde gabriel testi kullanılmıştır. Araştırmanın değişkenleri arasındaki ilişki pearson korelasyon analizi ile test edilmiştir. Elde edilen bulgular \%95 güven aralığında, \%5 anlamlılık düzeyinde değerlendirilmiştir.

Yetişkinlerin kitle iletişim araçlarıyla verilen sağlık haberlerini değerlendirme anketi "kişisel bilgiler", "sağlık/hastalık durumuna ait bilgiler" ve "sağlık eğitimde kullanılan kitle iletişim araçlarına ilişkin duygu ve düşünceler” ile ilgili soruların yer aldığ üç bölümden oluşmaktadır. Kişisel bilgilerin sorgulandığı birinci bölümde; "cinsiyet", "yaş", "medeni durum", "eğitim durumu”, "çalışma durumu”, "meslek” ile ilgi altı (6) soru sorulmuştur. Sağlık/hastalık durumunun sorgulandığı ikinci bölümde; "kronik bir hastalığın varlığı", "daha önce önemli bir hastalık ya da ameliyat geçirme durumu", "kendini bedenen ne kadar sağlıklı hissettiği" ve "kendini ruhen ne kadar sağlıklı hissettiğini” belirlemeye yönelik dört (4) soru sorulmuştur. İlk iki soru olan "kronik hastalığın varlığına" ve "daha önce önemli bir hastalık/ameliyat geçirme durumuna” yönelik sorulara "Evet" veya "Hayır” şeklinde cevap verilmesi istenmiştir. Diğer son iki soruda "kendini bedenen ne kadar sağlıklı hissettiği" ve "kendini ruhen ne kadar sağlıklı hissettiğine" yönelik sorulara "Çok İyi”, "İyi”, "Orta", "Kötü" veya "Çok Kötü” şeklinde cevap verilmesi istenmiştir. Sağlık eğitiminde kullanılan kitle iletişim araçlarına ilişkin duygu ve düşüncelerin sorgulandığı üçüncü bölümde; "sağlık konusundaki bilgi ve ihtiyaçları gidermede kitle iletişim araçlarından faydalanma sıklığı" ve "sağlık eğitiminde kitle iletişim araçlarına güvenme düzeyini” belirlemeye yönelik iki (2) soru sorulmuştur. Birinci soruda kitle iletişim araçları olarak alınan dergi, gazete, internet, radyo, televizyondan her birinden "sağlık konusundaki bilgi ve ihtiyaçları gidermede ne sıklıkta faydalandıkları" sorulmuş ve "Çok Sık" "Ara Sıra", "Nadiren” veya "Hiçbir Zaman” şeklinde cevap verilmesi istenmiştir. İkinci soruda "sağlı eğitiminde; kitle iletişim araçları olarak alınan dergi, gazete, internet, radyo, televizyondan her birine güvenme düzeyi" sorulmuş ve "Tamamen",

22 Ali Yıldırım ve Hasan Şimşek, Sosyal Bilimlerde Nitel Araştırma Yöntemleri, Ankara: Seçkin Yayınevi, 1999, s.73-75. 
"Çok", "Az" veya "Hiç" şeklinde cevap verilmesi istenmiştir.

Kitle iletişim araçlarıyla verilen sağlık eğitimi haberlerine yönelik tutum ölçeği toplamda 47 maddeden ve iki faktörden oluşmaktadır. Faktör analizi sonrasında tekrar hesaplanan ölçeğin bütününün iç tutarllık güvenilirliği cronbach $\alpha=0.866$ olarak, açıklanan varyans değeri ise \% 44.727 olarak saptanmıştır. Birinci faktör "Gerçeklik" olarak adlandırılmıştır. Gerçeklik faktörü, haberin doğru ve gerçek bilgiye dayanması, objektif bakış açısıyla yazılması ve yansıtılmasının yanı sıra gösteriş ve abartıdan uzak, basit, açık, eksiksiz ve doğru bir anlatıma sahip olmasını içermektedir. Bu faktör belirtilen tanımlama kapsamında yetişkinlerin haberin gerçekliğine ilişkin tutumlarını ölçmektedir. Bu faktör altında "Bilgi kirliliği oluşturur", "Hemen inanılmaması gereken haberlerdir", "farklı zamanlarda birbiriyle tutarsız bilgiler içerir" gibi maddelerden oluşan 24 madde yer almıştır. Gerçeklik faktörünü oluşturan 24 maddenin iç tutarlılık güvenilirliği cronbach $\alpha=0.936$ olarak, açıklanan varyans değeri ise \%23.706 olarak saptanmıştır. İkinci faktör "Önemlilik" olarak adlandırılmıştır. Önemlilik faktörü, haberin toplumsal, siyasal, ekonomik veya kültürel yaşa$\mathrm{m} ı$ doğrudan etkilemesi ve bu alanlarda herhangi bir gelişmeye veya değişime yol açmasını içermektedir. Bu faktör belirtilen tanımlama kapsamında yetişkinlerin haberin önemliliğine ilişkin tutumlarını ölçmektedir. Bu faktör altında "Yetişkinlerin sağlık sorunları hakkında bilincini arttırır", "Sağlıklı yaşam alışkanlıklarına yönelik mesajların topluma iletilmesinde etkilidir", "Sağlık konusunun gündemde tutulmasına katkıda bulunur" gibi maddelerden oluşan 23 madde yer almıştır. Önemlilik faktörünü oluşturan 23 maddenin iç tutarlılık güvenilirliği cronbach $\alpha=0.932$ olarak, açıklanan varyans değeri ise $\% 21,021$ olarak saptanmıştır.

\section{Araştırmanın Hipotezleri}

- $\mathrm{H}^{1}$ : Yetişkinlerin kitle iletişim araçlarıyla verilen sağlık haberlerine yönelik tutumları, sağlık konusundaki bilgi ihtiyaçlarını gidermede kitle iletişim araçlarından faydalanma sıklığına göre farklılaşmaktadır.

- $\mathrm{H}^{2}$ : Yetişkinlerin kitle iletişim araçlarıyla verilen sağlık eğitimi haberlerine yönelik tutumları, sağlık eğitiminde kullanılan kitle iletişim araçlarına olan güven derecesine göre farklılaşmaktadır.

- $\mathrm{H}^{3}$ : Yetişkinlerin sağlık konusundaki bilgi ihtiyaçlarını gidermede kitle iletişim araçlarından faydalanma sıklı̆ğ ile sağlık eğitiminde kullanılan kitle iletişim araçlarına güven düzeyleri arasında anlamlı ilişki vardır.

\section{Bulgular}

Tablo l'de araştırmaya katılanların tanımlayıcı özellikleri ile ilgili bulgular yer almaktadır. Yetişkinlerin “cinsiyet” değiş̧enine göre 112'si (\%53,8) kadın, 96’sı (\%46,7) erkek olarak dağılmaktadır. Yetişkinlerin "yaş” değişkenine göre 69'u $(\% 33,2) 25$ 29 yaş, 44 'ü $(\% 21,2) 30-34$ yaş, 39’u (\%18,8) 35-40 yaş, 32'si (\%15,4) 41-46 yaş, 5’i $(\% 2,4)$ 47-51 yaş, 19’u (\%9,1) 51 ve üstü olarak dağılmaktadır. Yetişkinlerin "medeni durum" değiş̧kenine göre 116'sı $(\% 55,8)$ evli, 92'si $(\% 44,2)$ bekâr olarak dağılmak- 
tadır. Yetişkinlerin "eğitim durumu” değişkenine göre 1'i $(\% 0,5)$ okuryazar değil, 12'si $(\% 5,8)$ ilkokul, 8’i $(\% 3,8)$ ortaokul, 53'ü $(\% 25,5)$ lise, 48'i $(\% 23,1)$ ön lisans, 71'i $(\% 34,1)$ lisans, 15 ’i $(\% 7,2)$ yüksek lisans olarak dağılmaktadır. Yetişkinlerin "meslek" değişkenine göre 66’sı (\%31,7) işçi, 82'si $(\% 39,4)$ memur, 12'si (\%5,8) ev hanımı, 6'sı $(\% 2,9)$ emekli, 10’u $(\% 4,8)$ öğrenci, 3'ü $(\% 1,4)$ işsiz, 29’u $(\% 13,9)$ diğer olarak dağılmaktadır. Yetişkinlerin "kronik hastalığın varlığı” değişkenine göre 52'si (\%25,0) evet, 156'sı (\%75,0) hayır olarak dağılmaktadır. Yetişkinlerin "hastalık veya ameliyat geçirme durumu” değişkenine göre 63’ü $(\% 30,3)$ evet, 145 ’i $(\% 69,7)$ hayır olarak dağılmaktadır. Yetişkinlerin "kendini bedenen sağlıklı hissetme durumu” değişkenine göre 39’u (\%16,2) çok iyi, 85’i $(\% 50,2)$ iyi, 70’i $(\% 33,7)$ orta, 12’si $(\% 5,8)$ çok kötü, 2'si (\%1,0) kötü olarak dağılmaktadır. Yetişkinlerin "kendini ruhen sağlıklı hissetme durumu” değişkenine göre 32'si $(\% 15,4)$ çok iyi, 74'ü $(\% 35,6)$ iyi, 76’sı $(\% 36,5)$ orta, 16 ’sı $(\% 7,7)$ kötü, 10’u $(\% 4,8)$ çok kötü olarak dağılmaktadır.

Tablo 1. Araştırmaya Katılanların Tanımlayıcı Özellikleri $(N=208)$

\begin{tabular}{|l|c|c|c|}
\hline Değişkenler & Gruplar & Frekans (n) & Yüzde (\%) \\
\hline Cinsiyet & Kadın & 112 & 53,8 \\
& Erkek & 96 & 46,2 \\
\hline Yaş & $25-29$ & 69 & 33,2 \\
& $30-34$ & 44 & 21,2 \\
& $35-40$ & 39 & 18,8 \\
& $41-46$ & 32 & 15,4 \\
& $47-51$ & 5 & 2,4 \\
& 51 ve Üzeri & 19 & 9,1 \\
\hline Medeni Durum & Evli & 116 & 55,8 \\
& Bekâr & 92 & 44,2 \\
\hline Eğitim Durumu & Okuryazar & 1 & 0,5 \\
& Değil & 12 & 5,8 \\
& İlkokul & 8 & 3,8 \\
& Ortaokul & 53 & 25,5 \\
& Lise & 48 & 23,1 \\
& Ön lisans & 71 & 34,1 \\
& Lisans & 15 & 7,2 \\
& Yüksek Lisans & & \\
\hline Hronik Hastalık Varlığı & İşçi & 66 & 31,7 \\
& Memur & 82 & 39,4 \\
& Ev Hanımı & 12 & 5,8 \\
& Emekli & 6 & 2,9 \\
& Öğrenci & 10 & 4,8 \\
& İşsiz & 3 & 1,4 \\
& Diğer & 29 & 13,9 \\
\hline Meslek & Evet & 52 & 25,0 \\
& Hayır & 156 & 75,0 \\
\hline & Evet & 63 & 30,3 \\
& Hayır & 145 & 69,7 \\
\hline
\end{tabular}




\begin{tabular}{|l|c|c|c|}
\hline Kendini Bedenen Sağlıklı Hissetme & Çok İyi & 39 & 18,8 \\
Durumu & İyi & 85 & 40,9 \\
& Orta & 70 & 33,7 \\
& Kötü & 12 & 5,8 \\
& Çok Kötü & 2 & 1,0 \\
\hline Kendini Ruhen Sağlıklı Hissetme Durumu & Çok İyi & 32 & 15,4 \\
& İyi & 74 & 35,6 \\
& Orta & 76 & 36,5 \\
& Kötü & 16 & 7,7 \\
& Çok Kötü & 10 & 4,8 \\
\hline
\end{tabular}

Araştırmaya katılan yetişkinlerin "gerçeklik" düzeyi tutum puanı orta $(3,084 \pm$ $0,820)$; “önemlilik" düzeyi tutum puanı orta $(2,789 \pm 0,777)$; "genel tutum” puanı orta $(2,946 \pm 0,477)$ olarak saptanmıştır. Yetişkinlerin kitle iletişim araçlarıyla verilen sağlık eğitimi haberlerine yönelik tutumlarının orta seviyede olduğu anlaşılmaktadir (Tablo 2).

Tablo 2. Yetişkinlerin Kitle İletişim Araçlarıyla Verilen Sağlık Eğitimi Haberlerine Yönelik Tutum Puanları

\begin{tabular}{|l|c|c|c|c|c|}
\hline & $N$ & Ortalama & Standart Sapma & Minimum & Maksimum \\
\hline Geçerlilik & 208 & 3,084 & 0,820 & 1,21 & 4,83 \\
\hline Önemlilik & 208 & 2,789 & 0,777 & 1,00 & 5,00 \\
\hline Genel Tutum & 208 & 2,946 & 0,477 & 1,43 & 4,55 \\
\hline
\end{tabular}

Araştırmaya katılan yetişkinlerin gerçeklik puanları ortalamalarının cinsiyet değişkenine göre anlamlı bir farklılık gösterip göstermediğini belirlemek amacıyla yapılan t-testi sonucunda grup ortalamaları arasındaki fark istatistiksel açıdan anlamlı bulunmamıştır $(t=-0,527 ; \mathrm{p}=0,599>0,05)$. Önemlilik puanı ortalamalarının cinsiyet değişkenine göre anlamlı bir farklılık gösterip göstermediğini belirlemek amacıyla yapılan t-testi sonucunda grup ortalamaları arasındaki fark istatistiksel açıdan anlamlı bulunmamıştır $(\mathrm{t}=0,958 ; \mathrm{p}=0,339>0,05)$. Genel tutum puanı ortalamalarının cinsiyet değişkenine göre anlamlı bir farklılık gösterip göstermediğini belirlemek amacıyla yapılan t-testi sonucunda grup ortalamaları arasındaki fark istatistiksel açıdan anlamlı bulunmamıştır $(\mathrm{t}=0,153 ; \mathrm{p}=0,878>0,05)$. Bu bulgudan hareketle yetişkinlerin kitle iletişim araçlarıyla verilen sağlık eğitimi haberlerine yönelik tutumlarının cinsiyetlerine farklılaşmadığı söylenebilir (Tablo 3).

Tablo 3. Yetişkinlerin Kitle İletişim Araçlarıyla Verilen Sağlık Eğitimi Haberlerine Yönelik Tutumlarının Cinsiyete Göre Farklılaşma Durumu

\begin{tabular}{|l|c|c|c|c|c|c|}
\hline & Grup & $N$ & Ortalama & Standart Sapma & $T$ & $p$ \\
\hline \multirow{2}{*}{ Geçerlilik } & Kadin & 112 & 3,056 & 0,887 & $-0,527$ & 0,599 \\
& Erkek & 96 & 3,117 & 0,737 & & \\
\hline \multirow{2}{*}{ Önemlilik } & Kadin & 112 & 2,837 & 0,779 & 0,958 & 0,339 \\
& Erkek & 96 & 2,733 & 0,775 & & \\
\hline \multirow{2}{*}{ Genel Tutum } & Kadin & 112 & 2,95 & 0,492 & 0,153 & 0,878 \\
& Erkek & 96 & 2,940 & 0,461 & & \\
\hline
\end{tabular}


Araştırmaya katılan yetişkinlerin gerçeklik puanı ortalamalarının yaş değişkenine göre anlamlı bir farklılık gösterip göstermediğini belirlemek amacıyla yapılan tek yönlü varyans analizi (Anova) sonucunda grup ortalamaları arasındaki fark istatistiksel açıdan anlamlı bulunmamıştır $(\mathrm{F}=1,591 ; \mathrm{p}=0,164>0.05)$. Önemlilik puanları ortalamalarının yaş değişkenine göre anlamlı bir farklılık gösterip göstermediğini belirlemek amacıyla yapılan tek yönlü varyans analizi (Anova) sonucunda grup ortalamaları arasındaki fark istatistiksel açıdan anlamlı bulunmamıştır $(\mathrm{F}=0,596 \mathrm{p}=0$, $0,703>0.05)$. Yaş değişkenine göre genel tutum puanları ortalamalarına uygulanan tek yönlü varyans analizi (Anova) sonucunda grup ortalamaları arasındaki fark istatistiksel açıdan anlamlı bulunmuştur $(\mathrm{F}=2,656$; $\mathrm{p}=0,024<0.05)$. Farklılıkların kaynaklarını belirlemek amacıyla tamamlayıcı post-hoc analizi yapılmıştır. Yaşı 35-40 yaş olanların önemlilik puanları $(3,098 \pm 0,434)$, yaşı 51 yaş üstü olanların önemlilik puanlarından $(2,699 \pm 0,604)$ yüksek bulunmuştur (Tablo 4$)$.

Tablo 4. Yetişkinlerin Kitle İletişim Araçlarıyla Verilen Sağlık Eğitimi Haberlerine Yönelik Tutumlarının Yaşa Göre Farklılaşma Durumu

\begin{tabular}{|l|c|c|c|c|c|c|c|}
\hline & Grup & $N$ & Ortalama & $\begin{array}{c}\text { Standart } \\
\text { Sapma }\end{array}$ & $F$ & $p$ & Fark \\
\hline \multirow{5}{*}{ Geçerlilik } & $25-29$ yaş & 69 & 3,010 & 0,797 & 1,591 & 0,164 & \\
& $30-34$ yaş & 44 & 3,117 & 0,893 & & & \\
& $35-40$ yaş & 39 & 3,332 & 0,592 & & & \\
& $41-46$ yaş & 32 & 3,093 & 0,811 & & & \\
& $47-51$ yaş & 5 & 3,183 & 0,962 & & & \\
& 51 ve üzeri & 19 & 2,728 & 1,028 & & & \\
\hline \multirow{5}{*}{ Onemlilik } & $25-29$ yaş & 69 & 2,688 & 0,762 & 0,596 & 0,703 & \\
& $30-34$ yaş & 44 & 2,905 & 0,762 & & & \\
& $35-40$ yaş & 39 & 2,822 & 0,689 & & & \\
& $41-46$ yaş & 32 & 2,864 & 0,855 & & & \\
& $47-51$ yaş & 5 & 2,878 & 0,924 & & & \\
& 51 ve üzeri & 19 & 2,670 & 0,901 & & & \\
Tutum & $25-29$ yaş & 69 & 2,857 & 0,419 & 2,656 & 0,024 & $3>6$ \\
& $30-34$ yaş & 44 & 3,020 & 0,520 & & & \\
& $35-40$ yaş & 39 & 3,098 & 0,434 & & & \\
& $41-46$ yaş & 32 & 2,982 & 0,451 & & & \\
& $47-51$ yaş & 5 & 3,021 & 0,388 & & & \\
\hline
\end{tabular}

Araştırmaya katılan yetişkinlerin gerçeklik puanı ortalamasının medeni durum değişkenine göre anlamlı bir farklılık gösterip göstermediğini belirlemek amacıyla yapılan t-testi sonucunda grup ortalamaları arasındaki fark istatistiksel açıdan anlamlı bulunmamıştır $(t=-0,275 ; \mathrm{p}=0,783>0,05)$. Önemlilik puanı ortalamasının medeni durum değişkenine göre anlamlı bir farklılık gösterip göstermediğini belirlemek amacıyla yapılan t-testi sonucunda grup ortalamaları arasındaki fark istatistiksel açıdan anlamlı bulunmamıştır $(t=1,169 ; \mathrm{p}=0,244>0,05)$. Genel tutum puanı ortalamasının medeni durum değişkenine göre anlamlı bir farklılık gösterip göstermedi- 
ğini belirlemek amacıyla yapılan t-testi sonucunda grup ortalamaları arasındaki fark istatistiksel açıdan anlamlı bulunmamıştır ( $\mathrm{t}=0,621 ; \mathrm{p}=0,535>0,05)$ (Tablo 5).

Tablo 5. Yetişkinlerin Kitle İletişim Araçlarıyla Verilen Sağlık Eğitimi Haberlerine Yönelik Tutumlarının Medeni Duruma Göre Farklılaşma Durumu

\begin{tabular}{|l|l|c|c|c|c|c|}
\hline & Grup & $N$ & Ortalama & Standart Sapma & $T$ & $p$ \\
\hline \multirow{2}{*}{ Geçerlilik } & Evli & 116 & 3,070 & 0,865 & $-0,275$ & 0,783 \\
& Bekâr & 92 & 3,102 & 0,764 & & \\
\hline \multirow{2}{*}{ Önemlilik } & Evli & 116 & 2,845 & 0,793 & 1,169 & 0,244 \\
& Bekâr & 92 & 2,718 & 0,755 & & \\
\hline \multirow{2}{*}{ Genel Tutum } & Evli & 116 & 2,964 & 0,490 & 0,621 & 0,535 \\
& Bekâr & 92 & 2,923 & 0,461 & & \\
\hline
\end{tabular}

Araştırmaya katılan yetişkinlerin gerçeklik puanları ortalamalarının eğitim durumu değişkenine göre anlamlı bir farklılık gösterip göstermediğini belirlemek amacıyla yapılan t-testi sonucunda grup ortalamaları arasındaki fark istatistiksel açıdan anlamlı bulunmamıştır $(\mathrm{F}=1,342 ; \mathrm{p}=0,240>0,05)$. Önemlilik puanları ortalamalarının eğitim durumu değişkenine göre anlamlı bir farklılık gösterip göstermediğini belirlemek amacıyla yapılan t-testi sonucunda grup ortalamaları arasındaki fark istatistiksel açıdan anlamlı bulunmamıştır ( $\mathrm{F}=0,968 ; \mathrm{p}=0,448>0,05)$. Genel tutum puanları ortalamalarının eğitim durumu değişkenine göre anlamlı bir farklılık gösterip göstermediğini belirlemek amacıyla yapılan t-testi sonucunda grup ortalamaları arasındaki fark istatistiksel açıdan anlamlı bulunmamıştır $(\mathrm{F}=0,910 ; \mathrm{p}=0,489>0,05)$ (Tablo 6).

Tablo 6. Yetişkinlerin Kitle İletişim Araçlarıyla Verilen Sağlık Eğitimi Haberlerine Yönelik Tutumlarının Eğitim Durumuna Göre Farklılaşma Durumu

\begin{tabular}{|l|l|c|c|c|c|c|c|}
\hline & \multicolumn{1}{|c|}{ Grup } & $N$ & Ortalama & $\begin{array}{c}\text { Standart } \\
\text { Sapma }\end{array}$ & $F$ & $p$ & Fark \\
\hline \multirow{5}{*}{ Geçerlilik } & Okuryazar değil & 1 & 1,541 &. & 1,342 & 0,240 & \\
& İlkokul & 12 & 2,802 & 0,880 & & & \\
& Ortaokul & 8 & 3,015 & 1,227 & & & \\
& Lise & 53 & 3,213 & 0,975 & & & \\
& Ön lisans & 48 & 3,193 & 0,581 & & & \\
& Lisans & 71 & 3,020 & 0,800 & & & \\
& Yüksek Lisans & 15 & 2,955 & 0,579 & & & \\
\hline \multirow{5}{*}{ Önemlilik } & Okuryazar değil & 1 & 3,260 & & 0,968 & 0,448 & \\
& İlkokul & 12 & 2,615 & 0,784 & & & \\
& Ortaokul & 8 & 3,114 & 0,759 & & & \\
& Lise & 53 & 2,630 & 0,805 & & & \\
& Ön lisans & 48 & 2,782 & 0,735 & & & \\
& Lisans & 71 & 2,871 & 0,800 & & & \\
& Yüksek Lisans & 15 & 2,921 & 0,697 & & & \\
\hline
\end{tabular}




\begin{tabular}{|l|l|c|c|c|c|c|c|}
\hline & Okuryazar değil & 1 & 2,361 &. & 0,910 & 0,489 & \\
Genel & İlkokul & 12 & 2,705 & 0,512 & & & \\
Tutum & Ortaokul & 8 & 3,031 & 0,808 & & & \\
& Lise & 53 & 2,939 & 0,521 & & & \\
& Ön lisans & 48 & 3,001 & 0,389 & & & \\
& Lisans & 71 & 2,953 & 0,475 & & & \\
& Yüksek Lisans & 15 & 2,944 & 0,311 & & & \\
\hline
\end{tabular}

Araştırmaya katılan yetişkinlerin önemlilik puanları ortalamalarının meslek durumu değişkenine göre anlamlı bir farklılık gösterip göstermediğini belirlemek amacıyla yapılan tek yönlü varyans analizi (Anova) sonucunda grup ortalamaları arasındaki fark istatistiksel açıdan anlamlı bulunmamıştır ( $\mathrm{F}=0,610 ; \mathrm{p}=0,722>0.05)$. Geçerlilik puanları ortalamalarının meslek durumu değişkenine göre anlamlı bir farklılık gösterip göstermediğini belirlemek amacıyla yapılan tek yönlü varyans analizi (Anova) sonucunda grup ortalamaları arasındaki fark istatistiksel açıdan anlamlı bulunmuştur $(\mathrm{F}=4,974 ; \mathrm{p}=0,000<0.05)$. Farklılıkların kaynaklarını belirlemek amacıyla tamamlayıcı post-hoc analizi yapılmıştır. Mesleği ev hanımı olanların geçerlilik puanları $(2,413 \pm 1,073)$ mesleği işçi olanların geçerlilik puanlarından $(2,990 \pm$ 0,447), yüksek bulunmuştur. Mesleği işçi olanların geçerlilik puanları $(2,990 \pm 0,447)$, mesleği emekli olanların geçerlilik puanlarından $(1,868 \pm 0,690)$ yüksek bulunmuştur. Mesleği memur olanların geçerlilik puanları (3,132 $\pm 0,631)$, mesleği ev hanımı olanların geçerlilik puanlarından $(2,413 \pm 1,073)$ yüksek bulunmuştur. Mesleği diğer olanların geçerlilik puanları $(3,204 \pm 0,745)$ mesleği emekli olanların geçerlilik puanlarından $(1,868 \pm 0,690)$, yüksek bulunmuştur. Mesleği diğer olanların geçerlilik puanları $(3,204 \pm 0,745)$, mesleği ev hanımı olanların geçerlilik puanlarından 2,413 $\pm 1,073)$ yüksek bulunmuştur. Mesleği memur olanların geçerlilik puanları $(3,132 \pm$ $0,631)$, mesleği emekli olanların geçerlilik puanlarından $(1,868 \pm 0,690)$ yüksek bulunmuştur. Genel tutum puanları ortalamalarının meslek durumu değişkenine göre anlamlı bir farklılık gösterip göstermediğini belirlemek amacıyla yapılan tek yönlü varyans analizi (Anova) sonucunda grup ortalamaları arasındaki fark istatistiksel açıdan anlamlı bulunmuştur $(\mathrm{F}=4,359 ; \mathrm{p}=0,000<0.05)$. Farklılıkların kaynaklarını belirlemek amacıyla tamamlayıcı post-hoc analizi yapılmıştır. Mesleği işçi olanların genel tutum puanları $(2,990 \pm 0,447)$, mesleği ev hanımı olanların genel tutum puanlarından $(2,560 \pm 0,512)$ yüksek bulunmuştur. Mesleği işçi olanların genel tutum puanları $(2,990 \pm 0,447)$, mesleği emekli olanların genel tutum puanlarından $(2,361$ $\pm 0,332)$ yüksek bulunmuştur. Mesleği memur olanların genel tutum puanları $(3,005$ $\pm 0,434)$, mesleği ev hanımı olanların genel tutum puanlarından $(2,560 \pm 0,512)$ yüksek bulunmuştur. Mesleği emekli olanların genel tutum puanları $(2,361 \pm 0,332)$, mesleği diğer olanların genel tutum puanlarından $(3,066 \pm 0,447)$ yüksek bulunmuştur. Mesleği diğer olanların genel tutum puanları (3,066 $\pm 0,447)$, mesleği ev hanımı olanların genel tutum puanlarından $(2,560 \pm 0,512)$ yüksek bulunmuştur (Tablo 7$)$. 
Tablo 7. Yetişkinlerin Kitle İletişim Araçlarıyla Verilen Să̆lık Eğitimi Haberlerine Yönelik Tutumlarının Meslek Durumuna Göre Farklılaşma Durumu

\begin{tabular}{|c|c|c|c|c|c|c|c|}
\hline & Grup & $N$ & Ortalama & $\begin{array}{c}\text { Standart } \\
\text { Sapma }\end{array}$ & $F$ & $P$ & Fark \\
\hline \multirow{7}{*}{ Geçerlilik } & İşçi & 66 & 3,258 & 0,892 & \multirow[t]{7}{*}{4,974} & \multirow[t]{7}{*}{0,000} & $1>4$ \\
\hline & Memur & 82 & 3,132 & 0,631 & & & $2>3$ \\
\hline & Ev hanımı & 12 & 2,413 & 1,073 & & & $2>4$ \\
\hline & Emekli & 6 & 1,868 & 0,690 & & & $3>1$ \\
\hline & Öğrenci & 10 & 2,750 & 0,742 & & & $7>3$ \\
\hline & İşsiz & 3 & 3,041 & 0,896 & & & $7>4$ \\
\hline & Diğer & 29 & 3,204 & 0,745 & & & \\
\hline \multirow{7}{*}{ Önemlilik } & İşçi & 66 & 2,682 & 0,825 & \multirow[t]{7}{*}{0,610} & \multirow[t]{7}{*}{0,722} & \\
\hline & Memur & 82 & 2,856 & 0,713 & & & \\
\hline & Ev hanımı & 12 & 2,753 & 0,865 & & & \\
\hline & Emekli & 6 & 2,956 & 1,116 & & & \\
\hline & Öğrenci & 10 & 2,660 & 0,750 & & & \\
\hline & İ̧̀siz & 3 & 2,434 & 0,805 & & & \\
\hline & Diğer & 29 & 2,905 & 0,768 & & & \\
\hline \multirow{7}{*}{ Genel Tutum } & İşçi & 66 & 2,990 & 0,477 & \multirow[t]{7}{*}{4,359} & \multirow[t]{7}{*}{0,000} & $1>3$ \\
\hline & Memur & 82 & 3,005 & 0,434 & & & $1>4$ \\
\hline & Ev hanımı & 12 & 2,560 & 0,512 & & & $2>3$ \\
\hline & Emekli & 6 & 2,361 & 0,332 & & & $4>7$ \\
\hline & Öğrenci & 10 & 2,693 & 0,491 & & & $7>3$ \\
\hline & İşsiz & 3 & 2,744 & 0,419 & & & \\
\hline & Diğer & 29 & 3,066 & 0,447 & & & \\
\hline
\end{tabular}

Araştırmaya katılan yetişkinlerin gerçeklik puanı ortalamasının kronik hastalığın varlığı değişkenine göre anlamlı bir farklılık gösterip göstermediğini belirlemek amacıyla yapılan t-testi sonucunda grup ortalamaları arasındaki fark istatistiksel açıdan anlamlı bulunmuştur $(\mathrm{t}=-4,888 ; \mathrm{p}=0,000<0,05)$. Hastalık olanların gerçeklik puanları $(x=3,564)$, hastalık olmayanların gerçeklik puanlarından $(x=3,043)$ yüksek bulunmuştur. Önemlilik puanı ortalamasının kronik hastalığın varlığı değişkenine göre anlamlı bir farklılık gösterip göstermediğini belirlemek amacıyla yapılan t-testi sonucunda grup ortalamaları arasındaki fark istatistiksel açıdan anlamlı bulunmamıştır $(t=0,319 ; \mathrm{p}=0,750>0,05)$. Genel tutum puanı ortalamasının kronik hastalığın varlığı değişkenine göre anlamlı bir farklılık gösterip göstermediğini belirlemek amacıyla yapılan t-testi sonucunda grup ortalamaları arasındaki fark istatistiksel açıdan anlamlı bulunmamıştır ( $\mathrm{t}=0,447 ; \mathrm{p}=0,655>0,05)$ (Tablo 8).

Tablo 8. Yetişkinlerin Kitle İletişim Araçlarıyla Verilen Sağlık Eğitimi Haberlerine Yönelik Tutumlarının Kronik Hastalı̆̆ın Varlı̆̆ına Göre Farklılaşma Durumu

\begin{tabular}{|l|l|c|c|c|c|c|}
\hline & Grup & $N$ & Ortalama & Standart Sapma & $T$ & $P$ \\
\hline \multirow{2}{*}{ Geçerlilik } & Evet & 52 & 3,043 & 0,894 & $-4,888$ & 0,000 \\
& Hayır & 156 & 3,564 & 0,741 & & \\
\hline
\end{tabular}




\begin{tabular}{|l|l|c|c|c|c|c|}
\hline \multirow{2}{*}{ Önemlilik } & Evet & 52 & 2,819 & 0,755 & 0,319 & 0,750 \\
& Hayır & 156 & 2,779 & 0,787 & & \\
\hline \multirow{2}{*}{ Genel Tutum } & Evet & 52 & 2,971 & 0,434 & 0,447 & 0,655 \\
& Hayır & 156 & 2,937 & 0,491 & & \\
\hline
\end{tabular}

Araştırmaya katılan yetişkinlerin gerçeklik puanları ortalamalarının hastalık veya ameliyat geçirme değişkenine göre anlamlı bir farklılık gösterip göstermediğini belirlemek amacıyla yapılan t-testi sonucunda grup ortalamaları arasındaki fark istatistiksel açıdan anlamlı bulunmuştur $(\mathrm{t}=-4,559 ; \mathrm{p}=0,000<0,05)$. Hastalık veya ameliyat olanların gerçeklik puanları $(\mathrm{x}=3,466)$, hastalık veya ameliyat olmayanların gerçeklik puanlarından $(x=3,031)$ yüksek bulunmuştur. Önemlilik puanları ortalamalarının hastalık veya ameliyat geçirme değişkenine göre anlamlı bir farklılık gösterip göstermediğini belirlemek amacıyla yapılan $\mathrm{t}$-testi sonucunda grup ortalamaları arasındaki fark istatistiksel açıdan anlamlı bulunmamıştır $(t=-1,055 ; p=0,293>0,05)$. Genel tutum puanları ortalamalarının hastalık veya ameliyat geçirme değişkenine göre anlamlı bir farklılık gösterip göstermediğini belirlemek amacıyla yapılan t-testi sonucunda t-testi sonucunda grup ortalamaları arasındaki fark istatistiksel açıdan anlamlı bulunmamıştır ( $\mathrm{t}=0,118 ; \mathrm{p}=0,906>0,05)$ (Tablo 9).

Tablo 9. Yetişkinlerin Kitle İletişim Araçlarıyla Verilen Sağlık Eğitimi Haberlerine Yönelik Tutumlarının Hastalı/Ameliyat Geçirme Durumuna Göre Farklılaşma Durumu

\begin{tabular}{|l|c|c|c|c|c|c|}
\hline & Grup & $N$ & Ortalama & Standart Sapma & $T$ & $p$ \\
\hline \multirow{2}{*}{ Geçerlilik } & Evet & 63 & 3,031 & 0,881 & $-4,559$ & 0,000 \\
& Hayır & 145 & 3,466 & 0,845 & & \\
\hline \multirow{2}{*}{ Onemlilik } & Evet & 63 & 2,703 & 0,706 & $-1,055$ & 0,293 \\
& Hayır & 145 & 2,827 & 0,806 & & \\
\hline \multirow{2}{*}{ Genel Tutum } & Evet & 63 & 2,952 & 0,429 & 0,118 & 0,906 \\
& Hayır & 145 & 2,943 & 0,497 & & \\
\hline
\end{tabular}

Araştırmaya katılan yetişkinlerin gerçeklik puanları ortalamalarının kendini bedenen sağlıklı hissetme değişkenine göre anlamlı bir farklılık gösterip göstermediğini belirlemek amacıyla yapılan tek yönlü varyans analizi (Anova) sonucunda grup ortalamaları arasındaki fark istatistiksel açıdan anlamlı bulunmamıştır ( $\mathrm{F}=1,437$; $\mathrm{p}=0,223>0.05)$. Önemlilik puanları ortalamalarının kendini bedenen sağlıklı hissetme değişkenine göre anlamlı bir farklılık gösterip göstermediğini belirlemek amacıyla yapılan tek yönlü varyans analizi (Anova) sonucunda grup ortalamaları arasındaki fark istatistiksel açıdan anlamlı bulunmamıştır $(\mathrm{F}=0,478 ; \mathrm{p}=0,752>0.05)$. Genel tutum puanları ortalamalarının kendini bedenen sağlıklı hissetme değişkenine göre anlamlı bir farklılık gösterip göstermediğini belirlemek amacıyla yapılan tek yönlü varyans analizi (Anova) sonucunda grup ortalamaları arasındaki fark istatistiksel açıdan anlamlı bulunmuştur $(\mathrm{F}=2,321 ; \mathrm{p}=0,058>0.05)$. Farklılıkların kaynaklarını belirlemek amacıyla tamamlayıcı post-hoc analizi yapılmıştır. Kendini bedenen sağ- 
lıklı hissetme çok iyi olanların genel tutum puanları $(2,944 \pm 0,561)$, kendini bedenen sağlıklı hissetme iyi olanların genel tutum puanlarından $(2,915 \pm 0,462)$ yüksek bulunmuştur. Kendini bedenen sağlıklı hissetme çok iyi olanların genel tutum puanları $(2,944 \pm 0,561)$, kendini bedenen sağlıklı hissetme orta olanların genel tutum puanlarından $(3,040 \pm 0,403)$ yüksek bulunmuştur (Tablo 10).

Tablo 10. Yetişkinlerin Kitle İletişim Araçlarıyla Verilen Sağlık Eğitimi Haberlerine Yönelik Tutumlarının Bedenen Sağlıklı Hissetme Durumuna Göre Farklılaşma

\section{Durumu}

\begin{tabular}{|l|c|c|c|c|c|c|c|}
\hline & Grup & $N$ & Ortalama & $\begin{array}{c}\text { Standart } \\
\text { Sapma }\end{array}$ & $F$ & $p$ & Fark \\
\hline \multirow{5}{*}{ Geçerlilik } & Çok iyi & 39 & 3,057 & 0,924 & 1,437 & 0,223 & \\
& İyi & 85 & 3,074 & 0,844 & & & \\
& Orta & 70 & 3,189 & 0,709 & & & \\
& Kötü & 12 & 2,805 & 0,869 & & & \\
& Çok Kötü & 2 & 2,062 & 0,147 & & & \\
& Çok iyi & 39 & 2,829 & 0,978 & 0,478 & 0,752 & \\
Önemlilik & Iyi & 85 & 2,738 & 0,772 & & & \\
& Orta & 70 & 2,865 & 0,646 & & & \\
& Kötü & 12 & 2,590 & 0,778 & & & \\
& Çok Kötü & 2 & 2,739 & 1,414 & & & \\
\hline \multirow{5}{*}{ Genel } & Çok iyi & 39 & 2,944 & 0,561 & 2,321 & 0,058 & $1>2$ \\
Tutum & Iyi & 85 & 2,915 & 0,462 & & & $1>3$ \\
& Orta & 70 & 3,040 & 0,403 & & & \\
& Kötü & 12 & 2,712 & 0,572 & & & \\
& Çok Kötü & 2 & 2,351 & 0,586 & & & \\
\hline
\end{tabular}

Araştırmaya katılan yetişkinlerin gerçeklik puanı ortalamasının kendini ruhen sağlıklı hissetme değişkenine göre anlamlı bir farklılık gösterip göstermediğini belirlemek amacıyla yapılan tek yönlü varyans analizi (Anova) sonucunda grup ortalamaları arasındaki fark istatistiksel açıdan anlamlı bulunmamıştır $(\mathrm{F}=0,669 ; \mathrm{p}=0,614>0.05)$. Önemlilik puanı ortalamasının kendini ruhen sağlıklı hissetme değişkenine göre anlamlı bir farklılık gösterip göstermediğini belirlemek amacıyla yapılan tek yönlü varyans analizi (Anova) sonucunda grup ortalamaları arasındaki fark istatistiksel açıdan anlamlı bulunmamıştır $(\mathrm{F}=1,043 ; \mathrm{p}=0,386>0.05)$. Genel tutum puanı ortalamasının kendini ruhen sağlıklı hissetme değişkenine göre anlamlı bir farklılık gösterip göstermediğini belirlemek amacıyla yapılan tek yönlü varyans analizi (Anova) sonucunda grup ortalamaları arasındaki fark istatistiksel açıdan anlamlı bulunmamıştır $(\mathrm{F}=0,817 ; \mathrm{p}=0,516>0.05)$. Bu bulgudan hareketle yetişkinlerin kitle iletişim araçlarıyla verilen sağlık eğitimi haberlerine yönelik tutumlarının kendini ruhen sağlıklı hissetme değişkenine göre farklılaşmadığı söylenebilir (Tablo 11). 
Tablo 11. Yetişkinlerin Kitle İletişim Araçlarıyla Verilen Sağlık Haberlerine Yönelik Tutumlarının Ruhen Sağlıklı Hissetme Durumuna Göre Farklılaşma Durumu

\begin{tabular}{|l|c|c|c|c|c|c|c|}
\hline & Grup & $N$ & Ortalama & $\begin{array}{c}\text { Standart } \\
\text { Sapma }\end{array}$ & $F$ & $p$ & Fark \\
\hline \multirow{5}{*}{ Geçerlilik } & Çok iyi & 32 & 2,977 & 0,986 & 0,669 & 0,614 & \\
& İyi & 74 & 3,115 & 0,803 & & & \\
& Orta & 76 & 3,130 & 0,789 & & & \\
& Kötü & 16 & 3,151 & 0,636 & & & \\
& Çok Kötü & 10 & 2,745 & 0,907 & & & \\
& Çok iyi & 32 & 2,739 & 1,018 & 1,043 & 0,386 & \\
\multirow{4}{*}{ Önemlilik } & İyi & 74 & 2,713 & 0,744 & & & \\
& Orta & 76 & 2,885 & 0,705 & & & \\
& Kötü & 16 & 2,611 & 0,622 & & & \\
& Çok Kötü & 10 & 3,073 & 0,875 & & & \\
Genel & Çok iyi & 32 & 2,855 & 0,540 & 0,817 & 0,516 & \\
Tutum & İyi & 74 & 2,927 & 0,449 & & & \\
& Orta & 76 & 3,018 & 0,482 & & & \\
& Kötü & 16 & 2,904 & 0,398 & & & \\
& Çok Kötü & 10 & 2,891 & 0,556 & & & \\
\hline
\end{tabular}

Tablo 12'ye göre araştırmaya katılan yetişkinlerin sağlık eğitimi ihtiyaçlarını gidermede "kitle iletişim araçlarından faydalanma sıklığı" düzeyi $(2,854 \pm 0,621)$ olarak saptanmıştır. Bu sonuca göre sağlık eğitimi ihtiyaçlarını gidermede kitle iletişim araçlarını "nadiren" kullanmaktadırlar.

Tablo 12. Yetişkinlerin Sağlık Eğitimi İhtiyaçlarını Gidermede Kitle İletişim Araçlarından Faydalanma Sıklı̆̆ı

\begin{tabular}{|l|c|c|c|c|c|}
\hline & $N$ & Ortalama & $\begin{array}{c}\text { Standart } \\
\text { Sapma }\end{array}$ & Minimum & Maximum \\
\hline $\begin{array}{l}\text { Kitle İletişim Araçlarını } \\
\text { Kullanma Sıklığ }\end{array}$ & 208 & 2,854 & 0,621 & 1,00 & 4,00 \\
\hline
\end{tabular}

Tablo 13'e göre araştırmaya katılan yetişkinlerin sağlık eğitiminde kullanılan "kitle iletişim araçlarına güvenme düzeyi” $(2,514 \pm 0,658)$ olarak saptanmıştır. Bu sonuca göre yetişkinler sağlık eğitiminde kullanılan kitle iletişim araçlarına "az" güvenmektedirler.

Tablo 13. Yetişkinlerin Sağlık Eğitiminde Kullanılan Kitle İletişim Araçlarına Güven Düzeyleri

\begin{tabular}{|l|c|c|c|c|c|}
\hline & $N$ & Ortalama & $\begin{array}{c}\text { Standart } \\
\text { Sapma }\end{array}$ & Minimum & \\
\hline $\begin{array}{l}\text { Kitle İletişim Araçlarına } \\
\text { Güvenme Düzeyi }\end{array}$ & 208 & 2,514 & 0,658 & 1,00 & 4,00 \\
\hline
\end{tabular}


Tablo 14'te önemlilik ile gerçeklik puanları arasında ters bir ilişsi vardır $(\mathrm{r}=-0,304$; $\mathrm{p}=0,000<0.05$ ). Buna göre önemlilik puanı arttıkça gerçeklik puanı azalmaktadır. Genel tutum ile gerçeklik puanları arasında istatistiksel açıdan anlamlı ilişki bulunmuştur $(r=0,693 ; p=0,000<0.05)$. Buna göre genel tutum puanı arttıkça gerçeklik puanı artmaktadır. Genel tutum ile önemlilik puanları arasında istatistiksel açıdan anlamlı ilişki bulunmuştur $(\mathrm{r}=0,473 ; \mathrm{p}=0,000<0.05)$. Buna göre genel tutum puanı arttıkça önemlilik puanı artmaktadır.

Kitle iletişim araçlarını kullanma sıklığı ile gerçeklik puanı arasında ters bir ilişki vardır $(r=-0,243 ; p=0,011<0.05)$. Buna göre kitle iletişim araçlarını kullanma sıklı̆̆ı arttıkça gerçeklik puanı azalmaktadır. Kitle iletişim araçlarını kullanma sıklığı ile önemlilik puanı arasında istatistiksel açıdan anlamlı ilişki bulunmuştur ( $\mathrm{r}=0,298$; $\mathrm{p}=0,000<0.05$ ). Buna göre kitle iletişim araçlarını kullanma sıklığı arttıkça önemlilik puanı artmaktadır. Kitle iletişim araçlarını kullanma sıklığı ile genel tutum puanı arasında ters bir ilişki vardır $(r=-0,002 ; p=0,977>0.05)$ Buna göre kitle iletişim araçlarını kullanma sıklı̆̆ arttıkça genel tutum azalmaktadır. Bu sonuca göre " $\mathrm{H}^{1}$ : Yetişkinlerin kitle iletişim araçlarıyla verilen sağlık eğitimi haberlerine yönelik tutumları, sağlık konusundaki bilgi ihtiyaçlarını gidermede kitle iletişim araçlarından faydalanma sıklığına göre farklılaşmaktadır” hipotezi kısmen kabul edilmiştir.

Kitle iletişim araçlarına güvenme düzeyi ile gerçeklik puanı arasında ters bir ilişki vardır $(r=-0,278 ; p=0,000<0.05)$. Buna göre kitle iletişim araçlarına güvenme düzeyi arttıkça gerçeklik puanı azalmaktadır. Kitle iletişim araçlarına güvenme düzeyi ile önemlilik puanı arasında istatistiksel açıdan anlamlı ilişki bulunmuştur ( $\mathrm{r}=0,423$; $\mathrm{p}=0,000<0.05$ ). Buna göre kitle iletişim araçlarına güvenme düzeyi arttıkça önemlilik puanı artmaktadır. Kitle iletişim araçlarına güvenme düzeyi ile genel tutum puanı arasında istatistiksel açıdan anlamlı ilişki bulunmamıștır $(r=0,058 ; \mathrm{p}=0,403>0.05)$. Buna göre kitle iletişim araçlarını güvenme düzeyi arttıkça genel tutum artmaktadır. $\mathrm{Bu}$ sonuca göre " $\mathrm{H}^{2}$ : Yetişkinlerin kitle iletişim araçlarıyla verilen sağlık eğitimi haberlerine yönelik tutumları, sağlık eğitiminde kullanılan kitle iletişim araçlarına olan güven derecesine göre farklılaşmaktadır" hipotezi kısmen kabul edilmiştir.

Kitle iletişim araçlarına güvenme düzeyi ile kitle iletişim araçlarını kullanma sıklığ 1 arasında istatistiksel açıdan anlamlı ilişki bulunmuştur $(r=0,574 ; \mathrm{p}=0,000<0.05)$. Buna göre kitle iletişim araçlarına güvenme güzeyi arttıkça kitle iletişim araçlarını kullanma sıklığı artmaktadır. Bu sonuca göre " $\mathrm{H}^{3}$ : Yetişkinlerin sağlık konusundaki bilgi ihtiyaçlarını gidermede kitle iletişim araçlarından faydalanma sıklığı ile sağlık eğitiminde kullanılan kitle iletişim araçlarına güven düzeyleri arasında anlamlı ilişki vardır" hipotezi kabul edilmiştir. 
Tablo 14. Yetişkinlerin Kitle İletişim Araçları ile Verilen Sağlık Eğitimi Haberlerine Yönelik Tutumları ile Sağlık Eğitiminde Kitle İletişim Araçlarını Kullanma Sıklı̆̆ı ve Kitle İletişim Araçlarına Güven Düzeyi Arasındaki İlişki

\begin{tabular}{|c|c|c|c|c|c|}
\hline & & Geçerlilik & Önemlilik & $\begin{array}{l}\text { Genel } \\
\text { Tutum }\end{array}$ & $\begin{array}{c}\text { Kitle iletişim } \\
\text { araçlarını } \\
\text { kullanma } \\
\text { sıklığı }\end{array}$ \\
\hline \multirow{2}{*}{ Önemlilik } & $\mathrm{R}$ & $-0,304^{* *}$ & 1,000 & & \\
\hline & $\mathrm{P}$ & 0,000 & 0,000 & & \\
\hline \multirow{2}{*}{ Genel Tutum } & $\mathrm{R}$ & $0,693^{* *}$ & $0,473^{* *}$ & 1,000 & \\
\hline & $\mathrm{P}$ & 0,000 & 0,000 & 0,000 & \\
\hline \multirow{2}{*}{$\begin{array}{l}\text { Kitle İletişim } \\
\text { Araçlarını Kullanma } \\
\text { Sıklığı }\end{array}$} & $\mathrm{R}$ & $-0,243^{* *}$ & $0,298^{* *}$ & $-0,002$ & 1,000 \\
\hline & $\mathrm{P}$ & 0,000 & 0,000 & 0,977 & 0,000 \\
\hline \multirow{2}{*}{$\begin{array}{l}\text { Kitle İletişim } \\
\text { Araçlarına Güvenme } \\
\text { Düzeyi }\end{array}$} & $\mathrm{R}$ & $-0,278^{* *}$ & $0,423^{* *}$ & 0,058 & $0,574^{* *}$ \\
\hline & $\mathrm{P}$ & 0,000 & 0,000 & 0,403 & 0,000 \\
\hline
\end{tabular}

\section{Sonuç}

Araştırmadan elde edilen sonuçlara göre yetişkinlerin kitle iletişim araçlarıyla verilen sağlık eğitimi haberlerini gerçekçi bulma, önemli bulma ve genel tutumları orta düzeydedir. Araştırma sonucunda ortaya çıkan bulgulara göre yetişkinlerin kitle iletişim araçlarıyla verilen sağlık eğitimi haberlerine yönelik tutumları cinsiyete göre anlamlı bir farklılık göstermemektedir. Fakat Simpkins ve Brenner'in bir araştırması sağlık haberlerinin daha çok kadınları ve yüksek gelir gruplarını ilgilendirdiğini ortaya koymuştur ${ }^{23}$. Oysaki sağlık haberleri yetişkinlere bireysel sağlıklarıyla ilgili mesajlar vermek yerine, daha çok toplum sağlığını koruma ve geliştirmeye ve sağlıkla ilgili farkındalığı ve bilgiyi arttırmaya yönelik mesajlar içermelidir.

Yetişkinlerin yaş ilerledikçe sağlık problemleri artmaktadır ve buna bağlı olarak sağlık konularına ve sağlık haberlerine ilgilerinin artması beklenmektedir. Yapılan araştırma sonucuna göre yetişkinlerin sağlık eğitimi haberlerini gerçekçi bulma ve genel tutumları yaşa göre anlamlı bir farklılık göstermemektedir fakat kitle iletişim araçlarıyla verilen sağlık eğitimi haberlerini; 35-40 yaş arası bireyler 51 ve üstü yaş bireylerden daha önemli bulmaktadırlar. Bunun yanı sıra sağlık eğitimi haberlerini gerçekçi bulma ve önemli bulma tutumları ile genel tutumları, medeni duruma göre anlamlı bir farklılık göstermemektedir. Eğitim seviyesi arttıkça bireylerin sağlık haberlerine inanmasının daha zor olacağı düşünülmektedir. Araştırma sonuçlarına göre düşünülenin tam tersi sağlık eğitimi haberlerini gerçekçi bulma ve önemli bulma tutumları ile genel tutumları, eğitim durumuna göre anlamlı bir farklılık göstermemektedir. Bireylerin meslekleri sağlık haberlerine yönelik tutumlarını etkile- 
mektedir. Kitle iletişim araçlarıyla verilen sağlık eğitimi haberlerini önemli bulma tutumları meslek durumuna göre anlamlı bir farklılık göstermemektedir. Gerçekçi bulma tutumları ve genel tutumları meslek durumuna göre anlamlı bir farklılık göstermektedir. Kitle iletişim araçlarıyla verilen sağlık eğitimi haberlerini mesleği ev hanımı olanlar işçi olanlara, mesleği işçi olanlar emekli olanlara, mesleği memur olanlar ev hanımlarına, diğer meslek grubuna sahip olanlar emekli olanlara göre daha gerçekçi bulmaktadır. Mesleği işçi olanların kitle iletişim araçlarıyla verilen sağlık haberlerine yönelik genel tutumları mesleği ev hanımı ve emekli olanlardan yüksek, mesleği ev hanımı olanların genel tutumları mesleği emekli ve diğer olanlardan düşüktür.

Yetişkinlerin kitle iletişim araçlarıyla verilen sağlık eğitimi haberlerini önemli bulma ve genel tutumları kronik bir hastalığın varlığına göre ve daha önce hastalık/ ameliyat geçirme durumuna anlamlı bir farklılık göstermemektedir. Gerçekçi bulma tutumları kronik bir hastalığın varlığına ve daha önce hastalık/ ameliyat geçirme durumuna göre anlamlı bir farklılık göstermektedir. Kronik bir hastalığı olan, daha önce ameliyat geçirmiş bireylerin olmayanlara göre kitle iletişim araçlarıyla verilen sağlık eğitimi haberlerini gerçekçi bulma tutumları daha olumludur. Bunun sebebi daha kronik hastalığı olan, daha önce ameliyat geçirmiş olan bireylerin sağlık ihtiyaçları fazla olduğu için haberlere inanma güdüsü daha fazla olacaktır.

Bireylerin kendilerini bedenen ve ruhen sağlıklı hissetmesi sağlık haberlerine yönelik tutumlarının belirlenmesinde önemli bir unsurdur. Yapılan araştırma sonucunda da yetişkinlerin kitle iletişim araçlarıyla verilen sağlık eğitimi haberlerini gerçekçi ve önemli bulma tutumlarının kendini bedenen sağlıklı hissetme durumuna göre anlamlı bir farklılık göstermediğini, genel tutumlarının kendini bedenen sağlıklı hissetme durumuna göre anlamlı bir farklılık gösterdiğini ortaya koymuştur. Kendini bedenen çok iyi hisseden bireylerin iyi ve orta hissedenlere göre kitle iletişim araçlarıyla verilen sağlı eğitimi haberlerini önemli bulma tutumları ve genel tutumları daha olumludur. Kendini ruhen sağlıklı hissetme durumuna göre ise anlamlı bir farklılık göstermediğini ortaya koymuştur.

Önemli diğer bir sonuç ise yetişkinler sağlık eğitimi ihtiyaçlarını gidermede kitle iletişim araçlarını "nadiren" kullanmakta ve az güvenmektedirler. Yetişkinlerin sağlık konusundaki bilgi ihtiyaçlarını gidermede kitle iletişim araçlarından faydalanma sıklığı ile sağlık eğitiminde kullanılan kitle iletişim araçlarına güven düzeyleri arasında istatistiksel açıdan anlamlı ilişki bulunmuştur. Buna göre yetişkinlerin sağlık eğitiminde kullanılan kitle iletişim araçlarına güvenme düzeyi arttıkça, sağlık eğitimi ihtiyaçlarını gidermede kitle iletişim araçlarından faydalanma sıklığı da artmaktadir.

Yetişkinlerin sağlı eğitimi ihtiyaçlarını gidermede kitle iletişim araçlarına güvenme düzeylerini ve sağlık eğitimi ihtiyaçlarını gidermede medyayı kullanma sıklıklarını arttırabilmek için bazı noktalara dikkat edilmesi gerekmektedir. Sağlık eğitimi haberleri yetişkinlere sunulurken amacının toplumun sağlığını koruma ve geliştirme olması, özel sağlık kuruluşlarının veya buralarda çalışan sağlık profesyonellerinin 
reklamlarının yapılmasından kaçınılması gerektiği düşünülmektedir. Sağlık haberleri yapılırken topluma sağlık davranışı kazandıracak haberlerin yapılmasına dikkat edilmelidir. Yetişkinlere, güvenlikleriyle ya da sağlıklarıyla ilgili sık karşılaşılan olumsuz durumlarda nasıl önlem alınacağına dair sağlık eğitimi haberleri, sağlık kuruluşlarının denetiminde sunulmalıdır.

Sağlık eğitimi haberi yapılırken kullanılacak olan kitle iletişim aracı (televizyon, radyo, internet, gazete, dergi), eğitimin verileceği hedef kitlenin özellikleri dikkate alınarak seçilmelidir. Ayrıca sağlık eğitimi için seçilen kitle iletişim aracının da, hedef kitle üzerinde en etkili olan kitle iletişim aracının olup olmadığına dikkat edilmelidir. Örneğin kırsal kesimde internet kullanımı yaygın değildir. Kırsal bölgedeki yetişkinlere verilecek sağlık eğitiminin internet üzerinden planlanması, sağlık eğitimi haberinin amacına ulaşmasını olumsuz etkileyecektir. Örneğin; benzer bir araştırma kırsal bölgelerde yapılıp, bireylerin sağlık eğitimi ihtiyaçlarını gidermede hangi kitle iletişim kanallarını kullandıkları ve tutumları belirlenebilir. Özellikle günümüzde yetişkinlerin sağlık eğitimi haberlerine yönelik tutumu etkileyen faktörlerin neler olduğuna ilişkin konularda yapılan araştırmaların sayısı oldukça yetersiz olup, bu alanlarda yeni araştırmalara ihtiyaç duyulmaktadır.

\section{Kaynakça}

Akgün, Gülsüm. "Yetişkinlerin Kitle İletişim Araçları Yoluyla Verilen Sağlık Eğitimi

Haberlerine Yönelik Tutumlarının Belirlenmesi”. Yüksek Lisans Tezi, Marmara Üniversitesi, 2014.

Çağatay, Güler ve Songül Vaizoğlu. “Toplum Sağlığı Eğitimi: Sağlık için Eğitim”. Yeni Türkiye. 39 (2001): 796-797.

Çınarlı, İnci. Sağlık İletişimi ve Medya. Ankara: Nobel Yayın Dağıtım, 2008.

Demir, Vedat. Medya Etiği. İstanbul: Beta Basım Yayın Dağıtım, 2006.

Duman, Ahmet. Yetişkinler Eğitimi. Ankara: Ütopya Yayınevi, 2007.

Geray, Cevat. Halk Eğitimi. Ankara: İmaj Yayınevi, 2002.

Gökkoca, F. Zuhal Ulusoy. "Sağlık Eğitimi Açısından Temel İlkeler”. Sürekli Tip Eğitimi Dergisi. 10/10 (2001): 371-374.

Güneş, Firdevs. Yetişkin Eğitimi. Ankara: Ocak Yayınları, 1996.

Girgin, Atilla. Gazeteciliğin Temel İlkeleri. İstanbul: Der Yayınları, 2008.

Lowe, Jone. Dünyada Yetişkin Eğitimine Toplu Bakış. Çev., Turhan Oğuzkan. Ankara: UNESCO Türkiye Milli Komisyonu, 1985.

Miser, Rıfat. Halk Eğitimi ve Toplum Kalkınması. Ankara: Türk Tarih Kurumu Basimevi, 1999.

Miser, Rıfat. "Küreselleșen Dünyada Yetişkin Eğitimi”. Ankara Üniversitesi Eğitim Bilimleri Fakültesi Dergisi. 35/1-2 (2002): 55-60.

Onur, Bekir. Gelişim Psikolojisi. Ankara: İmge Kitabevi, 2008.

Okçabol, Rıza. Halk Eğitimi (Yetişkin Eğitimi). Ankara: Ütopya Yayınevi, 2006.

Özden, Mehmet. Sağlık Eğitimi Ders Kitabı. Ankara: Kadığlu Maatbacılık, 1991.

Özden, Mehmet. Sağlık Eğitimi. Ankara: Feryal Matbaacılık, 1993. 
Park, Sung- Jung. "Korean Women's Development Institute; South Korea the Change of South Korean Adult Education in Globalization", International Journal of Lifelong Education. 21/3 (2002): 285-294.

Penirci, Gülşah. "Yetişkin Eğitimi Kurslarının Yetişkin Eğitimi ve Yetişkin Öğrenen İlke ve Özelliklerine Göre İncelenmesi”. Yüksek Lisans Tezi, Marmara Üniversitesi, 2014.

Yıldırım, Ali ve Hasan Şimşek. Sosyal Bilimlerde Nitel Araştırma Yöntemleri. Ankara: Seçkin Yayınevi, 1999.

Yüksel, Erkan. Medyanın Gündem Belirleme Gücü. Konya: Çizgi Kitabevi Yayınları, 2001. 
İNSAN\&İNSAN, Yıl/Year 5, Sayı/Issue 15, Kış/Winter 2018, 21-45

e-ISSN: 2148-7537, www.insanveinsan.org

\title{
Investigation of Adult Attitudes Towards Health News
}

\author{
YONCA YILDIRIM
}

\begin{abstract}
The aim of this research is to determine the attitudes of adults towards health education news delivered via mass media. The study was conducted on 208 outpatients who voluntarily participated in the research hospital in Kocaeli University Medical Faculty Hospital in April 2017 in accordance with the screening model. As a means of collecting data in the research, "Adults' Health Questionnaire Survey" and "Attitude Scale Towards Health News Given by Mass Media" developed by Akgün (2014) were used. Descriptive statistics and difference statistics were used in the analysis of the data. According to findings from the research, realistic finding, important finding and general attitudes towards health education news delivered by mass media are moderate. As the frequency of using the mass media increases as adults are getting away from their health education needs, the attitude of finding realistic and important health education news delivered by mass media is increasing. As the level of confidence in the mass media used in the health education of adults increases, the attitude of finding realistic and important health education news delivered by mass media is increasing.
\end{abstract}

Keywords: Adult education, Health education, Health news, Mass media. 